\title{
The True or the Idealized Self: How CEOS Build Their Personal Brands?
}

\author{
Anna M. Górska²
}

Submitted: 29.10.2020. Accepted: 8.03.2021

\section{Abstract}

Purpose: This study aims to empirically present the process of personal branding of CEOs. Building on the theoretical model proposed by Wojtaszczyk and Maszewski (2014), the study illustrates how CEOs build their personal brands.

Methodology: The study is based on twelve semi-structured interviews with the CEOs of Poland's strongest brands. Results were coded and analyzed with the use of MAXQDA software.

Results: The research allowed us to understand the process of creating a personal brand by CEOs. Moreover, interviews revealed that the personal brand reflects the true self of CEOs. However, it is also adjusted to the target audience; consequently, CEOs show diverse identities to the outside world.

Implications: Through the empirical investigation of the branding process, the findings fill a certain research gap. Insights gained in the process may prove useful for practitioners.

Originality/value: The article explores the subject of the personal brand, which continues to be the focus of many researchers, particularly in the CEE region. This research gave voice to CEOs, who explained how they build their personal brand and shared detailed information whose scope greatly exceeds what they present in the media.

Keywords: personal brand, CEO, personal branding process, CEO’s brand.

\section{JEL: M12; M39}

\footnotetext{
1 This article was created as a result of research project no. 2019/33/N/HS4/01574 financed by the National Science Centre under the PRELUDIUM grant and the ETIUDA scholarship no. 2019/32/T/HS4/00037 by the National Science Centre.

2 Kozminski University, Jagiellońska 57/59, 03-301 Warsaw, Poland, e-mail: amg@kozminski.edu.pl; https://orcid.org/0000-0003-3406-5454.
} 


\section{Introduction}

Interest in the personal brand and in personal branding significantly increased in recent years (Bendisch et al., 2013; Fetscherin, 2015; Fournier and Eckhardt, 2019; Parmentier et al., 2013; Scheidt et al., 2018). For individuals, the personal brand became a competitive advantage in careers (Gatewood et al., 1993; Schawbel, 2009), while for companies, the personal brand of their CEOs became an added value (Bendisch et al., 2013; Fetscherin, 2015; Scheidt et al., 2018).

Chief Executive Officers (CEOs) are widely recognized as figureheads for their organizations, and consequently, they are treated as brands (Bendisch et al., 2013; Fetscherin, 2015; Karaduman, 2013). The CEO is often regarded as the personification of the company; therefore, the CEO's position in the media discourse may attract the audience's attention to the CEO and, consequently, to the company as a whole (Bendisch et al., 2007). Previous studies conclude that the CEO's personal brand may have a positive impact on the company (Chen et al., 2013; Fetscherin, 2015; Ingenkoff and Sommer, 2010; Park and Berger, 2004; Love et al., 2017; Nolan, 2015; Wartwick, 1992). Researchers indicate the role of the CEO's personal brand in developing trust in the company (Ingenhoff and Sommer, 2010), but also in building the company's reputation (Broomley, 2001; Love et al., 2017), image (Park and Berger, 2004), and strategy (Solomon and Bendickson, 2016), not to mention creating positive associations and improving the public perception of the company (Meng and Berger, 2013). Moreover, CEOs are often associated with the company they represent; thus, they may transfer their personal brand onto the organization. Therefore, we should focus on understanding the process of building personal brands by CEOs from both a practical and an academic viewpoint.

Although the interest of academics in the personal brand systematically grows (Bendisch et al., 2013; Scheidt et al., 2018; Fournier and Eckhardt, 2019; Getchell and Beitelspacher, 2020), few empirical studies elaborated on the subject. Research focuses instead on how CEOs are portrayed in the media. However, no empirical research to date has investigated the process of CEO branding.

This study makes a number of contributions. First, it showcases the process of CEO branding based on empirical material and gives voice to the main actors. Existing studies mainly analyze the effects of CEOs' personal brands (Nolan, 2015; Scheidt et al., 2018), the presentation of the executive brand (Nanton and Dicks, 2015; Fournier and Eckhardt, 2019; Getchell and Beitelspacher, 2020), and its impact on the company (Kubowicz-Malhotra and Malhotra, 2016; Love et al., 2017). However, scholars pay little attention to the study of the personal branding process (Erdogmus and Esen, 
2018). Furthermore, this work proposes a new perspective from the methodological viewpoint, as most studies on personal brands base on social media monitoring (Chen et al., 2013; Love et al., 2017; Weng and Chen, 2017; Li et al., 2019), the analysis of specific cases (Fournier and Eckhardt, 2019), or the analysis of how a CEO's personal brand is perceived by the general public (Bendisch et al., 2013). In this light, this study answers the suggestion to consider CEOs' own voice in the process of understanding how they build their personal brands (Erdogmus and Esen, 2018).

In an attempt to fill this theoretical and methodological gap, I propose a model of CEO personal branding that empirically showcases how CEOs build their brands. The aim of this article is to answer the following research question:

RQ1: What is the process of CEO branding in the media?

The article begins with a review of the literature on CEO personal branding and its sources. The literature review showcases the diverging approaches of academics and practitioners to personal branding as a conscious or unconscious process, to personal branding strategies, and finally, the process of personal branding suggested by Wojtaszczyk and Maszewski (2014). Subsequently, I describe research methods and analyze data. The fourth section presents findings, followed by a discussion of results and conclusions.

\section{Personal Branding Literature Review}

Personal brand definitions are often general, and they do not reflect the managerial nature of the personal brand (Bendisch et al., 2013). Therefore, to define the personal brand, I refer to the primary understanding of brand in management science. If the brand is generally thought of as a set of associations invoked by certain goods or services (Keller, 2008), then the personal brand can be regarded as a "set of associations identified with a particular person” (Parmentier et al., 2013, p. 375), while a CEO's personal brand is a set of associations that a particular CEO invokes.

\section{Personal Branding as Conscious or Unconscious Behavior}

Whether an individual has an intrinsic brand or needs to create a brand consciously and intentionally remains a matter of debate. Hearn (2008) suggests that everyone has a brand, that it constantly develops, and that having a personal brand is inevitable. According to Hearn, we brand ourselves at any moment of social contact, whenever 
others analyze our actions and behaviors. His perception of the branding phenomenon concurs with practitioners' viewpoint (see Peters, 1997; Arruda, 2003; Montoya, 2002).

Shepherd (2005) and Hearn (2008) claim that everyone has a personal brand, which is to be a sign of distinction. On the other hand, others argue that personal branding is rather a conscious process with a clear aim and goal (Roffler, 2002; Khedher, 2014). Labrecque et al. (2011) suggest that we build personal brands either consciously - as explicitly expressed information - or contextually, as implicitly expressed information. This means that personal branding may involve unconscious behavior when individuals are not in control of the information they share. Labrecque et al. (2011) suggest that personal branding may be unconscious, and thus uncontrolled, while it remains evaluated and assessed by the public and has an impact on one's self-projection. In this view, we do not have full control over our image projected to the public. Even when presenting ourselves online, through conscious and intended actions, there remains a part beyond our control that influences the personal brand. In the online branding process, it is not only the content that individuals share and post that influences the brand but also other provided information (OPI) or how others describe the person (Walther and Parks, 2002; Rui and Stefanone, 2013). Moreover, Rein, Kotler, and Stoller (1997) argue that other information provided is crucial for the personal brand. Particularly in the case of celebrities, credible sources of information about a personal brand are testimonies from one's closest circle, i.e. family members, coworkers, and friends who best know the person behind the brand.

Within the notion of implicit and explicit expression of information, personal branding may be constantly influenced by the intentional and unintentional behavior of individuals, who may even be unaware of certain actions they take (Peters, 1997).

Therefore, personal branding means a constant behavior that occurs on both a conscious and unconscious level (Labrecque et al., 2011) and may remain beyond our control. Lair et al. (2005) argue that personal branding "does not appear to be for everyone, nor does it send the message that it is" (p. 330). According to this idea, although personal branding means a constant behavior while the personal brand is formed in the minds of others (Hearn, 2008), it remains our decision whether to consciously and intentionally brand ourselves beyond the image we already possess. Rein et al. (2006) approach the matter of the personal brand similarly: although "each person is different and will have an image in his or her social and professional circle whether or not he or she has done any conscious brand building” (p. 5). Thus, conscious and controlled personal brand creation is crucial in order to achieve one's goals. 


\section{Personal Branding Strategies}

There are two prevalent approaches to the process of brand formation: brand as a reflection of true self and brand as the reflection of market needs. Although, most scholars (Peters, 1997; 1999; Roffler, 2002; Arruda, 2003; Khedher, 2014) agree that the personal brand should reflect one's true self. Shepherd (2005) argues that in the process of self-marketing, the concept is frequently advocated by career advisers, who encourage their clients to develop skills desired by the market. Meanwhile, Peters (1997; 1999) emphasizes how an individual should be effectively marketed without the reconstruction of the product, i.e. the self. Shepherd (2005) notices that this approach is based on an "outmoded philosophy of marketing - viz. a product marketing approach" (p. 593). Thus, according to available sources, I distinguish two opposing strategies of personal branding: a) the true self approach (Peters, 1997; 1999), and b) the consumer-oriented approach (Bendisch et al., 2011; Khedher, 2014). In the consumer-oriented approach, individuals build their personal brand based on the identification of valuable skills and characteristics, and they incorporate these elements depending on the industry and audience (Khedher, 2014). This approach intends a perception that is a crucial element of self-branding, customized and adapted for specific audiences. Another self-branding strategy relies on the idea of presenting one's true self to a target audience, i.e. to "work with what you've got, and make it special" (Peters, 1997, p. 7). Moreover, Peters claims that in personal branding individuals are not expected to go through makeovers or to adapt to consumers. Instead, this approach encourages individuals to perform a thorough audit and discover their "real" self, which is only then presented to a target audience (Peters, 1997). Therefore, there is a conflict regarding the source of a personal brand: it may be intrinsic and based on our own values or extrinsic and based on market needs. There appears to be a conflict between these approaches as individuals are expected to act in line with marketing principles and respond to consumers, while at the same time remaining "truthful" to their own brand image based on their uniqueness (Shepherd, 2005).

The conflict between the two strategies of self-branding arises regarding whether one should remain honest and base the brand on one's own unique value proposition (Shepherd, 2005) or respond to the audience in line with marketing principles (Hern, 2008). Although academics argue which approach is truer, these views do not have to run counter to each other but can be considered complementary. Rein et al. (2006) suggest that as "each person is different" (p. 6), each of us can have a brand based on our personal characteristics. At the same time, people can consciously transform their brands in order to attain certain goals. 
Just as in the case of product branding, it is not only product properties or features that are sold; for it is equally important how they are communicated: "the brand is not just the product, but it gives the product meaning and defines its identity in both time and space" (Kapferer, 1997, p. 17). Therefore, in addition to who one actually is, the personal brand adds a projection: self-presentation (Hearn, 2008).

Sirgy (1982) claims that the concept of personal branding involves the creation of an idealized self or what we would like to be, not what we actually are. Similarly, Goffman (1956) claimed that self-presentation means delivering to the audience an idealized performance rather than the true self. Research by Back et al. (2010) published in Psychological Science does not support this theory. On the example of social media, they claim that we do not present to the world our idealized identity and that social media are means for expressing and communicating our real personality. These findings support the research by Vazire and Gosling (2004) and Labrecque et al. (2011). Although the personal brand might be created consciously, it still holds certain characteristics of the branded person.

\section{Personal Branding Process}

Wojtaszczyk and Maszewski (2014) suggest that personal branding is a process that consists of planning, organizing, acting, and controlling. Similarly, Khedher (2014) and Rampersad (2009) suggest that the process of personal branding should begin with the identification of the individual's characteristics, skills, and traits; only later should one introduce acting. We should remember that just as in the case of traditional brands, the means of communication of a brand should also be carefully considered to allow reaching target groups (Gaines-Ross, 2015). Based on the above literature review, I suggest that personal branding follows a specific process (Figure 1).

Figure 1. The process of personal branding

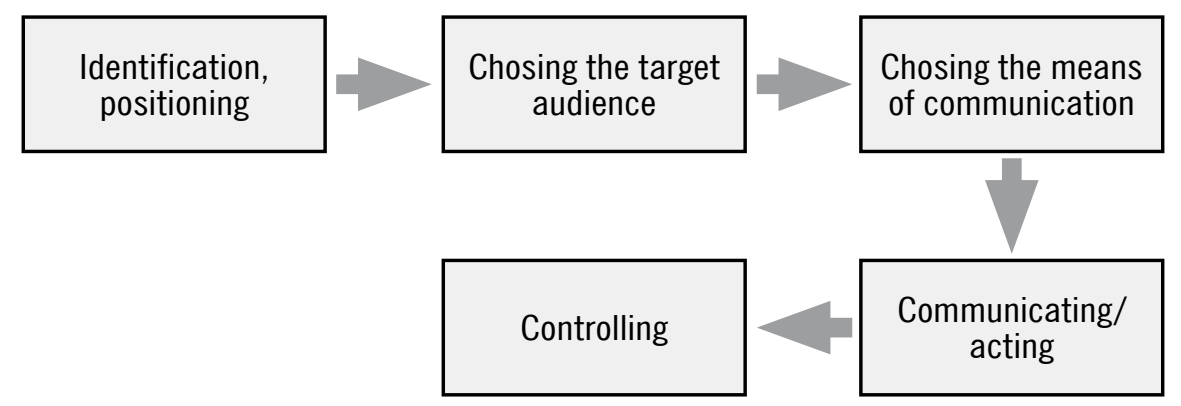

Source: own elaboration based on Wojtaszczyk and Maszewski (2014). 


\section{Method}

In order to understand the process of CEO personal branding, I conducted twelve interviews with current or former CEOs of Poland's strongest brands (Rzeczpospolita Ranking, 2018; see Appendix 1). The choice of the method was deliberate and connected with the article's research goals. I decided to employ semi-structured individual interviews as they allow respondents to present their own perspectives and opinions on the matter under scrutiny, which is important in order to gain a comprehensive understanding. Moreover, personal branding is a subjective phenomenon, and therefore including the individual actor's perspective is highly important. On the one hand, semi-structured interviews allow the interviewer to ensure that research questions and desired topics are covered, while they simultaneously allow for a degree of flexibility and control over the conversation.

To choose the right participants for the interview, I utilized the method of purposive sampling. Respondents were selected to form a sample based on their experience as CEOs of companies listed by the Rzeczpospolita daily. Moreover, I decided to interview both company founders and appointed CEOs. Allow me to emphasize how difficult it was to arrange meetings with CEOs of Poland's strongest brands. Interviews began in September 2018 and the qualitative part of the research continued until February 2019.

Interviews were conducted in the CEOs' native language, i.e. in Polish. Most interviews were held face to face or over the phone, recorded, and subsequently transcribed by a specialist company; in the case of two interviews conducted face to face, I did not receive permission to record the meetings; instead, I took thorough notes for further data analysis. Whenever the respondents granted explicit permission, I recorded the interviews and took notes. Each semi-structured interview lasted between 50 and 80 minutes.

The interview outline was created based on the general themes that emerge from the literature. 1) How CEOs understand the personal brand? 2) How CEOs build their personal brand? 3) What are the steps of building the personal brand? 4) How do you assess the importance of media in building the personal brand? Interview scenario enabled for the deepening of interviews while allowing enough flexibility to respondents for the free expression of thoughts.

I used MAXqda software for the purpose of coding and analyzing interviews. This tool has been created for researchers who regularly evaluate and interpret qualitative texts (Creswell, 2008). The method of open, axial, and selective coding was applied 
in order to classify the data into coding categories (Strauss and Corbin, 1998). All information that could be tracked back to respondents was anonymized, including interviewees' names, companies, and industries in which they operate.

\section{Findings}

Based on the theoretical model of personal branding suggested by Maszewski and Wojtaszczyk (2014), I identified subsequent stages of CEO branding. This process includes the identification of one's values and positioning, the choice of the target audience, the means of communication, and control. The interviews confirmed that the CEOs follow this process and its subsequent stages.

\section{Self-Identification}

Although the majority of CEOs claim that they have an idea of how they wish to be perceived and what forms part of their personal brand, brand building does not seem to be an organized or planned process.

Many CEOs emphasize that they want to be perceived as experts in their field and industry. In their contacts with the media, they try to focus on their knowledge, expertise, and skills, which form the core of their personal brand. It seems that the CEOs are mindful about how they present themselves and carefully chose the topics they intend to discuss in the media:

When I speak, I speak about the industry, about the things that I know and understand. This is something I want to be associated with. I can't speak about stuff I don't understand (R9).

[the personal brand] must be reliable... if, for example, I brand myself as competent, there must be a level of competence to back me up, right? If I brand myself as an expert, I must be an expert, it must be visible in my actions, and they must confirm that I am an expert in this particular field (R12).

It seems that CEOs build their personal brand on their actual and true self. Their personal brand results from their character and mindset that are further translated into actions. This is what the respondents emphasized in multiple interviews. Moreover, the CEOs stressed the importance of their personal brand's coherence, which is reflected throughout their public activity, actions and messages: 
The personal brand must be coherent, it can't be that a person is seen differently depending on the place ... it must be authentic, otherwise it will not be coherent. It can't be this weird creation; it would not be real. A personal brand reflects a real product, a real person (R11).

At the same time, interviewees are aware that their identity may change depending on the circumstances, but maintaining consistency remains key:

Obviously, one is different when with one's friends, during a business meeting, at a restaurant, and at home ... as long as it is consistent and real (R11).

Thus, it seems that the personal brand reflects one's core self, which is consistent, while one's behavior is adjusted to the circumstances. In the eyes of respondents, coherence is crucial and must even include one's sense of fashion and style. Moreover, the interviewees emphasized that it is crucial for them to set themselves apart from other CEOs:

[the personal brand] is not only something that makes you recognizable, right?

It also differentiates you from other CEOs (R3).

Differentiation was stressed in several contexts. It is clear that it is for the CEOs important to stand out in terms of expertise. One of the CEOs mentioned that although differentiation is an important element of the personal brand, it remains somehow constrained:

My brand differentiates me, but I still can't be too different, like an outlier among CEOs, I mean there are certain rules of the game we stick to, so I cannot be too extravagant, for example in the way I dress or behave (R1).

It seems that the interviewed CEOs have a general idea about how they want to be seen, what they want to be associated with, what their points of convergence and difference ought to be. The example above illustrates the idea of "standing out while fitting in" (Parmenter et al., 2012). It seems that although CEOs want to set themselves apart from one another, they avoid challenging the norms generally accepted in their environment.

\section{Choice of Target Audience}

Another step in the personal branding process is the choice of the target audience. The interviewees emphasized that although their personal brand is first and foremost 
aimed at the business environment, serves to establish business relations, and build credibility, the target audience is often much broader:

I think that it is mostly aimed at business partners, not to mention personal contacts, as my personal brand remains also within these contacts; but I believe it is aimed at potential clients, too. It is a matter of presenting the company's CEO and it has to do with building trust in the company ... personal contacts with other CEOs are also beneficial for business, so yes, my personal brand is targeted at a broad audience (R2).

The CEOs emphasize that despite being their potential target, the general public is difficult to reach, and it is hard to adjust content to its expectations:

I want to be recognizable among business partners and investors, but also the public. They are my potential clients, but the problem lies in reaching them. I don't want to be associated with tabloids, while an average person does not read papers in which I am featured. [Public recognition] is difficult to attain (R3).

Some interviewees stressed the importance of being recognizable for potential clients, as the CEO not only acts as the company face in business relations but also plays a role in building trust among clients: "It is mainly targeted at consumers so that they trust us" (R8). Some interviewees also emphasized that they are unwilling to be public personas, and their brand is limited only to their business environment. As one of the interviewed CEOs put it:

I'm not a public figure in the way politicians are, so [the personal brand] is aimed specifically at the business environment, at the broadly defined business environment ... although there are CEOs, for instance, Mr. X [one of the interviewed CEOs], who use their faces to reach clients (R7).

It seems that the CEOs of companies from consumer industries (such as FMCG or tourist services) deem it more important to reach potential clients (Rennebook and Zhao, 2015). They seem to place more emphasis on reaching potential clients, and they do not limit their personal brand specifically to the business environment, but also address the general public and clients. The target audience of the personal brand of a CEO is broad, includes multiple types of stakeholders (Donaldson and Preston, 1995; Bendisch, 2011), and is not limited to business professionals. 


\section{Choice of Means of Communication}

When it comes to personal brand communication, the CEOs emphasize the importance of the press and the Internet, while TV and the radio are considered less important. According to the interviewees, TV and the radio disallow an in-depth discussion, as they are more interested in short pieces of information that "make a good story" (R7). The CEOs emphasized that the press and the Internet are better means of building the personal brand, as they enable a freer presentation and speech without devaluing the discussed matter:

The only opportunity to discuss a complex issue is an interview in the press or online ... it's not going to happen on TV or on the radio (R3).

TV journalists want a hot topic, short and catchy, they are not interested in your expert opinion. It is not the best way of conveying an important message (R7).

The interviewees stressed that the choice of topics is important for maintaining a coherent and credible image. Thus, the CEOs build personal brands based on their expert knowledge, which requires them to carefully choose media channels in which they want to appear. The CEOs classify types of media they use for the purpose of brand building depending on the audience they want to reach. According to one of the CEOs:

Journals X and Y support me whenever I need to tell something to the investors ... [but] when I want to say something to the general public, for example, when I make a statement related to an extraordinary situation in the company ... I go to TV station Z (R5).

It seems that the CEOs distinguish between types of media in order to adjust their message to the target audience. The choice of media sources like a TV or Radio stations or journals are also important for the interviewees. They stressed that they avoid TV or Radio stations or journals that do not represent their values or whose image does not tally with how they want to be perceived; they do not wish to be associated with certain publishers.

I know where I can and can't go. When I know it's going to look bad for me, or when there is a risk of my words being twisted, I firmly refuse, and I do not participate (R9). 
There is this one medium: Y. It used to be a decent newspaper, I mean... we all know the story. Ever since they appointed a new editor-in-chief, it has become a tabloid ... we receive invitations from them, they even call us ..., but we don't want to have anything to do with them. We don't want to be associated with it in any way .... In the case of top newspapers, I mean top in terms of quality and reputation, such as $\mathrm{Z}$ or $\mathrm{X}$, we know it is important for us (R9).

The CEOs are not only aware of differences in terms of audiences depending on the type of media but also adjust their message depending on the outlet:

Well, I need to prepare differently depending on the media type .... Whenever I go to an expert interview, I prepare some data that may be useful, but when I go to a less specialist media outlet, I always have a couple of anecdotes up my sleeve (R7).

It seems that when present in the media, the CEOs are mindful of both the matter to be discussed and the channel. They carefully choose the topics and the media they want to be associated with, and they act accordingly. At the same time, they have no control over how they are presented when their original statement is reposted in other printed and online sources.

\section{Communicating/Acting}

Interviewees recognize behaviors that can contribute to building a personal brand. CEOs emphasize that the personal brand of a CEO can be built through networking and public appearances at conferences or in the media. Although CEOs view networking as an important element of their personal branding process, they know that it is targeted at a rather specific and limited audience, while media appearances are those that enable CEOs to communicate their personal brand to a wider audience, hence often are more impactful.

Moreover, the interviewees are aware that their personal branding methods significantly differ from the average persons', as they have unique access to broader audiences through the national and local media:

I know that my personal brand-building strategy is different from, for example, that of Mr. Kowalski. I have the press and TV inviting me to talk about certain topics because of my position as a company representative. If it was a smaller company or a less interesting organization, I wouldn't have such possibilities (R4). 
The CEOs stress that conferences, training, and lectures are means of presenting oneself as a professional and expert in a certain domain that gives one legitimization, while they emphasize that such events have a significantly smaller audience than the mass media:

I don't know which is more effective: at conferences, I meet people who are often from the same industry, interested in the subject matter, while through the press I can reach my future clients (R10).

Interviewees emphasize that media appearances are an important element of their personal brand building as they enable the general public to get to know them:

We live in the times of the media and of social media, and I think that a brand is worthless if it is not present in the media, be it the Internet along with all that social media stuff, the radio, or TV. What is the use of a brand that nobody writes or talks about? It is worthless (R4).

The CEOs emphasized that the main way in which they build their personal brands in the media is when they have an opportunity to present themselves as experts in a certain domain. Thus, appearances unrelated to their expertise are seen as "acting like a celebrity" (R16), which would not add anything valuable to one's personal brand.

It seems that the social media activity of CEOs is subject to less deliberation. Some interviewees use social media for personal branding, while others either abstain from using them altogether or use them for private purposes only. Only four are active users of social media yet their communication is not strictly related to work; it seems that they use it for both professional and private communication. The majority of those who are not present in social media claimed to be concerned about their privacy:

For me [using social media] means a kind of exposure of my privacy. Generally, I have an issue with the Internet as a safe means of sharing information, so I don't tweet, I don't chat, I don't use Facebook, Instagram, or even LinkedIn, which is my conscious, deliberate choice. If someone wants to find me, they will, anyway ... I am already too recognizable (R7).

Another interviewee claimed that although she has her private social media profile, she does not use it for the purposes of CEO personal branding, and her presence in social media is limited to observing others. Having said that, she seems aware of the benefits it could bring: 
I have my private profile, of course, I even thought about creating a professional one. We have spoken about it with my PR manager many times, and had I been a CEO for longer, I might have used it for professional purposes ..., but for me, it would rather be a problem, as I don't like to put myself out there (R1).

Those among the interviewed CEOs who are active on social media claim that they use them for personal branding, although the scope and level of their engagement differ substantially. They put great emphasis on communication with stakeholders. They find it particularly useful when presenting their personal successes or company news. The interviewees see their personal social media accounts as a means of building not only their own personal brand but that of the company as well:

I often write articles for Facebook or LinkedIn on new technologies, company news, or the economy, right? I try to inform people about what is going on ..., but I also present myself as an authority on the topic .... I publish at least once a week (R2).

For some of the interviewed CEOs, social media are crucial as a channel that allows them to maintain personal contact with a broader audience; they allow for quick and responsive communication. One of the CEOs emphasized that she uses social media - Twitter in particular - to build her credibility and present herself as an expert by commenting and displaying her opinions on current events:

I have to be there, I have to tweet sometimes, this is how I maintain contact with a broader audience, how I tell them what I believe in, and how I educate them (R11).

Others have also stressed that it is an important tool for keeping in touch with the general public, neglected as it may be: "I know I should be more active [on social media] and represent the company, but I just don't have the time" (R3). Only two of the interviewed CEOs emphasize that they are mindful of what they publish online, and they think about the possible consequences:

I use my LinkedIn account to promote my personal brand .... I use it to share ideas connected with my professional life, I am very cautious about what I post, I carefully chose the content to be published (R4).

However, the accounts of many CEOs lack professionalism as the CEOs claim to treat them as a means of communication somewhere between their professional and private lives: 
I mean my profile is both private and professional ... from time to time, I post information about my garden ..., but there is, generally, more professional information .... I run it specifically to promote the company (R2).

I keep my social media accounts for both my friends and the general public. I post professional information about our success, something we are proud of, but I may publish a funny picture, too (R3).

Thus, it seems that although interviewees distinguish among types of traditional media and are aware of methods of navigating among different audiences, they still find it difficult to understand the purpose of using different kinds of social media and their value for personal branding.

\section{Controlling}

As argued by Wojtaszczyk and Maszewski (2014), the final element of the personal branding process is controlling. It seems that controlling is not commonly used by the interviewed CEOs, as only a few of them explicitly stated that they monitor and control their media appearances; in most cases, controlling is organized by the company:

There is media monitoring, so somebody brings me those sheets of paper with information on what has been written about me (R4).

Thus, controlling seems more the initiative of companies than of the CEOs. One of the CEOs found reading about himself rather unpleasant and so strongly reacted when his personal brand was attacked:

I wish sometimes that I didn't [read about myself], I don't want to read these comments and react to what people write about me ... I react differently to those articles. There have been many situations in which I could have sued them, but I did it only once .... I sued the editor of a right-wing newspaper following a personal attack when they compared me to Yanukovych, but it ended amicably, they apologized (R7).

Another CEO also claims that he reacts to media content regarding him:

I have to [react], if there is something that may negatively affect my image .... If there is a question, some kind of misunderstanding, whenever I can, I try to 
fix it, when there is a conference or an interview ... you have to constantly react, as I said earlier, you have to very firmly react to such events (R4).

These two examples show that some CEOs not only monitor but also control how they are presented in the media. Other CEOs did not explicitly state whether and how they control their personal brand in the media. Moreover, my questions about media monitoring proved that CEOs do not comment or respond to online articles in the comment section. Thus, their engagement is visible only on their social media profiles.

\section{Discussion and Conclusions}

The findings of this study support what is suggested by Wojtaszczyk and Maszewski (2014) regarding the process of personal branding. Evidence from the interviews shows that, in fact, the CEOs not only communicate and act according to their personal brand in the media but also plan it and - some of them - control it to a certain extent. Personal branding in the media seems to be a deliberate and conscious process (Rein et al., 2005); although, as emphasized by the interviewees, it remains the outcome of one's true self (Back et al., 2010). Thus, the CEOs are conscious about how they wish to be perceived and what image they intend to convey depending on the public, the medium, or the topic (Karaduman, 2013). They are particularly mindful of how their appearances might be received by various stakeholders in their professional brand (i.e. the CEO brand). Moreover, Zerfass et al. (2016) find that although a great emphasis seems to be put on the creation of the CEO's personal brand, still very few companies monitor and control it in further stages of development.

Although personal branding is often criticized in the academic discourse as a presentation of an idealized version of oneself (Sirgy, 1982), my interviews suggest that it is considered rather as an ongoing action, be it deliberate or not. Thus, the personal brand is not associated with pretending or with deliberately misguiding others (Sirgy, 1982; Khedher, 2014) but rather as a reflection of the person itself in question (Peters 1999; Rein et al., 2006). Thus, the study demonstrates that the CEO personal brand is not a deliberately idealized image to be conveyed, as argued by Sirgy (1982), but rather a reflection of the CEO in question. For the interviewees, the personal brand stems from one's true self, from one's character, mindset, and actions. They also emphasized the contextuality of the personal brand: one may have a strong personal brand in a particular discipline but not in another one. The interviewees emphasized that a person can be seen differently depending on the context and the topic, thus referring 
to the idea of multiple brands that relate to one's diverse roles in life (Schau and Gilly, 2003; Shepherd, 2005).

It seems that the interviewees follow the process of personal branding described in the literature, which includes the identification of one's values and positioning, the choice of the target audience, the choice of the means of communication, along processes of communicating and controlling. The existence of all these stages was confirmed throughout my interviews. First, the interviewed CEOs have a general idea of how they want to be perceived, with what they want to be associated, and what their points of parity and differentiation are (Parmentier et al., 2013). Second, CEOs consciously adjust the topic to the target audience. Subsequently, the choice of the means of communication is subject to careful deliberation, although they seem to understand social media - and their use - less than traditional media. Although previous research suggested that the CEOs avail themselves of social media to present their professional rather than private self (Kim et al., 2015; Toppinen et al., 2015; Kubowicz-Malhotra and Malhotra, 2016; Zerfass et al., 2016), the interviews evidence that CEOs tend to avoid social media altogether. In the case of those who are active, communication is not limited to professional information but consists also of publishing private content.

Finally, there is evidence to suggest that CEOs not only monitor but also control their image presented in the media. The CEOs are conscious of how they want to be perceived and of the image they wish to convey depending on the public, the medium, or the subject of talk (Karaduman, 2013). Similarly, as argued by Goffman (1956), CEOs adjust their communication to the audience, and therefore they seem to distinguish between different types of audiences and to adapt the content to the particular needs and expectations of the latter.

The interviewed CEOs also emphasized that they intend to be perceived as professional. Consequently, their presence in various media is to allow them to showcase their skills and expertise. The following study enabled me to understand the process of CEOs' personal branding in the eyes of the CEOs.

\section{Practical Implications, Limitations, and Future Research Recommendations}

In addition to academic contributions, my research contributes to organizations and CEOs. Specifically, it is to support the managerial practices on how to utilize and manage a CEO's personal brand. As this research was conducted in a specific region 
and the managerial contributions are dedicated to Polish companies, others should treat it with caution. Moreover, the research was based on large companies with strong and recognizable brands, thus not all CEOs have similar possibilities to build their personal brand through traditional media.

The article has also certain limitations. The major limitation is connected with the availability of the CEOs. Although in my opinion data were saturated, additional interviews could still benefit the study. The CEOs' perspective could also be biased and not based on the actual process of brand building but rather on their idea of the process. The CEOs themselves may not be the only ones responsible for their professional personal brand, thus what would prove useful would be an additional perspective from public relations managers or chief marketing officers so as to broaden our understanding of how CEOs personal brands are constructed.

The fact that the research was conducted in Poland - based on data of Polish CEOs - limits the reach of the study. Thus, one may argue that the results are country-specific and should not be extrapolated to other regions. However, this research provides a theoretical framework to study CEO brands outside Poland, specifically in the Central and Eastern Europe region, where the research connected with a personal brand is still limited in general and, specifically, regarding the CEO brand.

Another limitation of the article is that I did not consider the importance of the corporate brand in CEO branding, thus underrepresenting the company's brand in how CEOs build and communicate their own brand, which is an important topic for further studies. Specifically, I would recommend future research on the alignment between the two brands.

Moreover, future research should investigate the subject of personal branding with the use of a mixed methods approach to gain a comprehensive understanding of how CEOs' personal brands are constructed, specifically with tools of media monitoring helping to understand the visibility and presentation of CEOs in the media. Furthermore, studies that would investigate the use of social media could prove useful, basing on the quantitative monitoring of accounts (Górska et al., 2020; Mazurek et al., 2020).

Finally, I should also mention that CEOs' personal brands are not neutral when it comes to gender (Getchell and Beitelspacher, 2020). Studies indicate that CEOs are differently perceived and evaluated depending on their gender (Górska, 2017), thus future studies on differences in how men and women build personal brands are highly recommended. 


\section{References}

Arruda, W. (2003). An Introduction to Personal Branding: a revolution in the way we manage our careers. Available at:

https://www.reachcc.com/reachdotcom.nsf/bfb4f3685c4706d2c1256ad1005d5e63/79325a245696e988c1256de000431539/Body/M2/intropersonalbrandingv3.pdf!OpenElement (05.2018).

Back, M., Stopfer, J., Vazire, S., Gaddis, S., Schmukle, S., Egloff, B. and Gosling, S.D. (2010). Facebook profiles reflect actual personality, not self-idealization. Psychological Science, 21(3), 372-374. https://doi.org/10.1177/0956797609360756.

Bendisch, F. (2011). Branding CEOs: How relationship between chief executive officers, corporate brands and stakeholders' image can influence perceived brand value, $\mathrm{PhD}$ Thesis, under the supervision of G. Larsen and M. Trueman, Bradford University School of Management.

Bendisch, D., Larsen, G. and Trueman, M. (2007). Branding people: towards a conceptual framework. Working paper series, 22(22), 3-28.

Bendisch, F., Larsen, G. and Trueman, M. (2013). Fame and Fortune: A Conceptual Model of CEO Brands. European Journal of Marketing, 47, 596-614. https://doi.org/10.1108/03090561311297472.

Broomley, D.B. (2001). Relationships between personal and corporate reputation. European Journal of Marketing, 35(3-4), 316-328. https://doi.org/10.1108/03090560110382048.

Chen C., Yi, B and Lin, J. (2013). Media coverage, board structure and CEO compensation: Evidence from Taiwan. Journal of Multinational Financial Management, 23(5), 434-445. https://doi.org/10.1016/j.mulfin.2013.08.003.

Creswell, J. (2008). Research Design: Qualitative, Quantitative, and Mixed Methods Approaches. Third Edition. California: Sage.

Donaldson, T. and Preston, L. (1995). The Stakeholder Theory of the Corporation: Concepts, Evidence, and Implications. The Academy of Management Review, 20(1), 65-91. https://doi.org/10.5465/amr.1995.9503271992.

Erdogmus, N. and Esen, E. (2018). Constructing the CEO Personal Brand: The case of Four Pioneering CEOs in Turkey. Corporate Reputation Review, 21(1), 37-49. https://doi.org/10.1057/s41299-017-0042-3.

Fetscherin, M. (2015). How does CEO reputation Matter? Impact of CEO reputation on corporate reputation and performance. In: M. Fetscherin (ed.), CEO Branding. London: Routledge. https://doi.org/10.4324/9781315795140.

Fournier, S. and Eckhardt, G.M. (2019). Putting the person back in person-brand: Understanding and managing the two-bodied brand. Journal of Marketing Research, 56(4), 602-619. https://doi.org/10.1177/0022243719830654.

Gaines-Ross, L. (2015). The emergence of the Social CEO. In: M. Fetscherin (ed.), CEO Branding, (pp. 348-365), London: Routledge.

Gatewood, R.D., Gowan, M. and Lautenschalger G. (1993). Corporate image, recruitment image and initial job choice decisions. Academy of Management Journal, 36, 414-427. https://doi.org/10.2307/256530.

Getchell, K.M., and Beitelspacher, L.S. (2020). Better marketing for female marketers: Gendered language in the Forbes CMO list. Business Horizons. https://doi.org/10.1016/j.bushor.2020.04.004.

Goffmann, E. (1956). The Presentation of Self in Everyday Life. New York: Doubleday. Gofton.

Górska, A. (2017). Perception of women in top managerial positions in Poland. Journal of Business and Administration. Central Europe, 25, 16-32. https://doi.org/10.7206/jmba.ce.2450-7814.187. 
Górska, A. Korzynski, P. Mazurek, G. and Pucciarelli, F. (2020). The Role of Social Media in Scholarly Collaboration: An Enabler of International Research Team's Activation? Journal of Global Information Technology Management, 23(4), 273-291. https://doi.org/10.1080/1097198X.2020.1817684.

Hearn, A. (2008). Meat, mask, burden: probing the contours of the branded self. Journal of consumer culture, 8(2), 197-217. https://doi.org/10.1177/1469540508090086.

Ingenhoff. D. and Sommer, K. (2010). Trust in companies and in CEOs: A comparative study of the main influences. Journal of Business Ethics, 95(1), 339-355. https://doi.org/10.1007/s10551-010-0363-y.

Kapferer, J.N. (1997). Strategic Brand Management. Creating and Sustaining Brand Equity Long Term. London: Kogan Page.

Karaduman, I. (2013). The effect of social media on personal branding efforts of top level executives. Procedia-Social and Behavioral Sciences, 99, 465-473. https://doi.org/10.1016/j.sbspro.2013.10.515.

Keller, K. (2008). Strategic Brand Management: A European Perspective. Harlow: Pearson Education. Keller.

Khedher, M. (2014). Personal branding phenomena. International Journal of Information, Business and Management, 6(2).

Kim, H., Park, J., Cha, M. and Jeong, J. (2015). The effect of bad news and CEO apology of corporate on user responses in social media. PLOS ONE, 10(5), 1-21. https://doi.org/10.1371/journal.pone.0126358.

Kubowicz-Malhotra, C. and Malhotra, A. (2016). How CEOs can leverage Twitter. MIT Sloan Management Review, 57, 72-79.

Labrecque, L.I., Markos, E. and Milne, G.R (2011). Online personal branding: Processes, Challenges and Implications. Journal of Interactive Marketing, 25(1), 37-50. https://doi.org/10.1016/j.intmar.2010.09.002.

Lair, D., Sullivan, K. and Cheney, G. (2005). Marketization and the recasting of the professional self. Management Communication Quarterly, 18(3), 307-343. https://doi.org/10.1177/0893318904270744.

Li, X., Wong, W., Lamoureux, E. and Wong, T. (2012). Are linear regression techniques appropriate for analysis when the dependent (outcome) variable is not normally distributed? Investigative Ophthalmology and Visual Science, 53, 3082-3083. Available at:

https://iovs.arvojournals.org/article.aspx?articleid=2128171 (07.2019). https://doi.org/10.1167/ iovs.12-9967.

Love, E.G., Lim, J., and Bednak M.K. (2017). The face of the firm: the influence of CEOs on corporate reputation. Academy of Management Journal, 60, 1462-1481. https://doi.org/10.5465/amj.2014.0862.

Mazurek, G., Gorska, A., Korzynski, P. and Silva, S. (2020). Social Networking Sites and Researcher's Success. Journal of Computer Information Systems. https://doi.org/10.1080/08874417.2020.1783724.

Meng, J. and Berger, B.K. (2013). What they say and what they do: executives affect organizational reputation through effective communication. In: C.E. Carroll (ed.), The handbook of communication and corporate reputation, New Jersey: Wiley. https://doi.org/10.1002/9781118335529.ch26.

Montoya, P. (2002). The personal branding phenomenon. Personal Branding Press.

Nolan, L. (2015). The impact of executive personal branding on non-profit perception and communication, Public Relations Review, 41, 288-292. https://doi.org/10.1016/j.pubrev.2014.11.001.

Park, D.J. and Berger, B.K. (2004). The presentation of CEOs in the press, 1990-2000: Increasing salience, positive valence, and a focus on competency and personal dimensions of image. Journal of Public Relations Research, 16, 93-125. https://doi.org/10.1207/s1532754xjprr1601_4.

Parmentier, M.A., Fischer, E. and Reuber, A. (2013). Positioning personal brands in established organizational fields. Academy of Marketing Science, 41(1), 373-387.

https://doi.org/10.1007/s11747-012-0309-2.

Peters T. (1997). The brand called you. Fast Company, 10, 83-89. 
Peters, T. (1999). The Brand You. Fifty Ways to Transform Yourself from an "Employee" into a Brand That Shouts Distinction, Commitment and Passion!, New York: Alfred A. Knopf Publisher.

Rennebook, L. and Zhao, Y. (2015). CEO Networks and the M\&A Market. In: M. Fetscherin (ed.), CEO Branding. London: Routledge.

Rein, I., Kotler, P. and Stoller, M. (2006), High Visibility: The Making and Marketing of Professionals into Celebrities, 3rd Ed. Lincolnwood: NTC Business Books.

Roffler, R.F. (2002). Make a Name for Yourself Eight steps every woman needs to create a personal brand strategy for success. New York, NY: Broadway.

Rui, J. and Stefanone, M. (2012). Strategic self-presentation online: A cross-cultural study. Computers in human behavior, 29(1), 110-118. https://doi.org/10.1016/j.chb.2012.07.022.

Rzeczpospolita ranking (2018). Available at: http://www.rp.pl/Marki-Polskie/301259825-Mocne-krajowe-marki-wspieraja-polska-gospodarke.html (03.2018).

Schau, H. and Gilly, M. (2003). We are what we post? Self-presentation in Personal Web Space. Journal of Consumer Research, 30(3), 385-404. https://doi.org/10.1086/378616.

Schawbel, D. (2009), Personal branding 2.0. Cztery kroki do zbudowania osobistej marki. Warszawa: OnePress.

Scheidt, S., Gelhard, C., Strotzen, J. and Henseler, J. (2018). In for a penny, in for a pound? Exploring mutual endorsement effects between celebrity CEOs and corporate brands. Journal of Product and Brand Management, 27(2), 203-220. https://doi.org/10.1108/JPBM-07-2016-1265.

Shepherd, I. (2005). From Cattle to Coke to Charlie: Meeting the Challenges of Self Marketing and Personal Branding. Journal of Marketing Management, 21(5), 589-606. https://doi.org/10.1362/0267257054307381.

Sirgy, J. (1982). Self-Concept in Consumer Behavior: A Critical Review. Journal of Consumer Research, 9(3), 287-300. https://doi.org/10.1086/208924.

Solomon, S.J., and Bendickson, J. (2016). Generating press, bold ideas and stubbornness: The impact of celebrity CEOs. Journal of Business Strategies, 32, 67-93.

Strauss, A., and Corbin, J. (1998), Basics of qualitative research: Procedures and techniques for developing grounded theory. Sage Publications, Thousand Oaks, CA.

Toppinen, A., Hanninen, V. and Lahtinen, K. (2015). ISO 26000 in the assessment of CSR communication quality: CEO letters and social media in the global pulp and paper industry. Social Responsibility Journal, 11(4), 702-715. https://doi.org/10.1108/SRJ-09-2013-0108.

Vazire, S. and Gosling, S. (2004). e-Perceptions: personality impressions based on personal websites. Journal of Personality and Social Psychology, 1, 123-132. https://doi.org/10.1037/0022-3514.87.1.123.

Walther, J.B., and Parks, M. (2002). Cues filtered out, cues filtered in: Computer-mediated communication and relationships. In: M. Knapp and J. Daly (eds.), Handbook of Interpersonal Communication (529-563). Thousand Oaks:Sage.

Wartwick, S. (1992). The relationship between intense media exposure and change in corporate reputation. Business and Society, 41, 371-392. https://doi.org/10.1177/000765039203100104.

Weng, P.S. and Chen, W.Y. (2017). Doing good or choosing well? Corporate reputation, CEO reputation, and corporate financial performance. North American Journal of Economics and Finance, 39, 223-240. https://doi.org/10.1016/j.najef.2016.10.008.

Wojtaszczyk, K. and Maszewski, F. (2014). Różnorodność metod zarządzania marką osobistą. Prace Naukowe Uniwersytetu Ekonomicznego we Wrocławiu, 1(349), 454-462. https://doi.org/10.15611/pn.2014.349.38.

Zerfass, A., Verčič, D. and Wiesenberg, M. (2016). Managing CEO communication and positioning. Journal of Communication Management, 20(1), 37-55. https:/doi.org/10.1108/JCOM-11-2014-0066. 


\section{Appendix}

Table 1. Information about the interviewees

\begin{tabular}{|c|c|c|c|c|}
\hline Code & $\begin{array}{c}\text { Respondent } \\
\text { position } \\
\text { (at the time } \\
\text { of the interview) }\end{array}$ & $\begin{array}{c}\text { Company ranked } \\
\text { by RP } 2017 \\
\text { (Rzeczpospolita, } \\
\text { 2018) }\end{array}$ & Type of interview & Category \\
\hline $\mathrm{R} 1$ & Former CEO & YES & Face to face, transcribed & Telecommunication \\
\hline R2 & $\begin{array}{l}\text { Former CE0, } \\
\text { founder }\end{array}$ & YES & Face to face, transcribed & Services \\
\hline R3 & CE0, founder & YES & $\begin{array}{l}\text { Phone interview, } \\
\text { extended notes taken }\end{array}$ & Services \\
\hline R4 & CEO & YES & Face to face, transcribed & Non-food products \\
\hline R5 & CE0, founder & YES & $\begin{array}{l}\text { Phone interview, } \\
\text { transcribed }\end{array}$ & Non-food products \\
\hline R6 & CEO, founder & YES & Face to face, transcribed & Sweets and ice-cream \\
\hline R7 & CEO & YES & Face to face, transcribed & Media and publishing \\
\hline R8 & CEO & YES & $\begin{array}{l}\text { Phone interview, } \\
\text { transcribed }\end{array}$ & $\begin{array}{l}\text { Clothing, shoes, } \\
\text { and accessories }\end{array}$ \\
\hline R9 & CE0, founder & YES & Face to face, transcribed & Cosmetics and hygiene \\
\hline R10 & $\begin{array}{l}\text { Former CEO, } \\
\text { founder }\end{array}$ & YES & $\begin{array}{l}\text { Face to face, extensive } \\
\text { notes taken }\end{array}$ & Cosmetics and hygiene \\
\hline R11 & $\begin{array}{l}\text { Former, CE0, } \\
\text { founder, } \\
\text { president }\end{array}$ & YES & Face to face, transcribed & Services \\
\hline R12 & $\begin{array}{l}\text { Former CE0, } \\
\text { founder }\end{array}$ & YES & Face to face, transcribed & Food products \\
\hline
\end{tabular}

Source: own elaboration. 